\title{
KIELITUTKINTO OHJAA OPETUSTA JA KANNUSTAA PUHUMAAN
}

\author{
Minna Martikainen, Jyväskylän yliopisto
}

\begin{abstract}
Tässä tutkimuksessa selvitetään vuosina 2003-2016 käytössä olleen kielitutkinnon vaikutuksia inkeriläisten paluumuuttajien paluumuuttovalmennukseen. Inkeriläisillä tarkoitan etnisiä suomalaisia, jotka ovat asuneet Venäjällä jo sukupolvien ajan. Voidakseen muuttaa Suomeen paluumuuttajastatuksen perusteella heidän piti suorittaa A2-tason kielitutkinto. Tutkimuksessa analysoin, kuinka opettajat kuvaavat tutkinnon vaikutusta opetukseensa. Opettajat työskentelivät Venäjällä ja opettivat suomea inkeriläisille, jotka aikoivat muuttaa Suomeen. Kurssin päätarkoituksena oli saavuttaa kielitutkinnossa vaadittu kielitaidon taso. Aineisto koostuu opettajien ja kielitutkintotyöryhmän asiantuntijoiden haastatteluista. Haastatteluissa pyysin opettajia kuvailemaan tutkinnon vaikutusta opetuksen sisältöön, menetelmiin ja luokkahuoneen ilmapiiriin. Keskeisimmiksi vaikutuksiksi nimettiin opetuksen sisältö ja tehtävätyypit, erityisesti puheharjoitukset, opiskelijoiden motivaatio ja kurssin selkeät tavoitteet.
\end{abstract}

Avainsanat: inkeriläiset, kielitutkinnot, suomen kieli, vaikutukset

\section{TUTKIMUKSEN TAUSTA}

Kielitutkintojen avulla tutkinnon suorittajat todentavat osaamistaan, mutta samalla tutkinnot saattavat vaikuttaa niin kielenopetuksen sisältöön ja menetelmiin kuin myös laajemmalle yhteiskuntaan (mm. Cheng \& Curtis, 2004; Wall, 1997). Kansainvälisten, erityisesti englannin kielen tutkintojen vaikutuksia on tutkittu jo runsaasti; tutkintojen vaikutuksia on tarkasteltu sekä luokkahuoneessa että sen ulkopuolella. Suomessa inkeriläisille paluumuuttajille räätälöitiin suomen kielen taitoa mittaava kielitutkinto vuonna 2003 ja perustelut, joita tutkinnon tarpeelli-

Kirjoittajan yhteystiedot:

Minna Martikainen

Jyväskylän yliopisto

minna.martikainen@tampere.fi suudesta esitettiin, olivat varsin moninaisia. Tämän tutkinnon vaikutuksia ei ole aiemmin tutkittu lainkaan.

Tässä artikkelissa analysoidaan inkeriläisten paluumuuttajien Dipaki-kielitutkinnon vaikutuksia valmennuskurssin opetukseen. Tavoitteena on selvittää, 1) millaisia tavoitteita tutkinnon opetusvaikutuksille aikanaan asetettiin, 2) miten tutkinnolle asetetut tavoitteet ovat toteutuneet ja 3) mitä muita, mahdollisesti ennalta suunnittelemattomia vaikutuksia sillä on ollut. 13 vuotta käytössä ollutta tutkintoa tarkastellaan siihen valmentavien opettajien ja kielitutkintoa valmistelleen työryhmän jäsenten puheessa. Valmennuskursseja on vuosien mittaan järjestetty pääasiassa Venäjällä, ja opettajina ovat toimineet paikalliset opettajat. Kielitutkintoja sen sijaan on järjestänyt Suomen viranomainen, aluksi työministeriö, myöhemmin sisäasianministeriön Maahanmuuttovirasto, sama 
viranomainen, joka on tehnyt oleskelulupapäätökset osin kielitutkintojen perustella. Oleskelulupien myöntäminen tällä niin sanotulla inkeriläisstatuksella päättyi kesällä 2016, jolloin päättyi myös kielitutkinnon käyttö.

Dipaki-tutkinto, josta ennen digitalisointia käytettiin nimitystä Ipaki, oli läpäisytutkinto. Kielitaitoa testattiin neljällä osa-alueella: puhuminen, puheen ymmärtäminen, kirjoittaminen ja tekstin ymmärtäminen. Hyväksyttyyn suoritukseen vaadittiin kaikkien neljän osakokeen suorittaminen ja puhumisen sekä jonkin muun osakokeen suorittaminen vähintään taitotasolla $\mathrm{A} 2$ (Kärkkäinen \& Lankinen, 2008; Työministeriö, 2003a). Kielitaidon saattoi todistaa myös Yleisen kielitutkinnon avulla, kun siitä sai vähintään taitotasoa A2 vastaavan arvosanan (Kärkkäinen \& Lankinen, 2008; Maahanmuuttovirasto, 2015; Dipaki-tutkinnon järjestelyistä Martikainen, 2016).

\section{TUTKINTOJEN VAIKUTUKSET LUOKKAHUONEESSA JA SEN ULKOPUOLELLA}

Kielitutkintojen vaikutuksista käytetään englanninkielisissä tutkimuksissa termejä impact ja wasback. Wall (1997) erottelee termit seuraavasti: impact on mikä tahansa vaikutus, joka tutkinnolla on yksilöihin tai käytäntöihin luokassa, koulussa, koulutusjärjestelmässä tai yhteiskunnassa kokonaisuutena. Washback-termin merkitys on rajatumpi. Sillä tarkoitetaan tutkinnon vaikutusta opetukseen ja oppimiseen (Cheng 2008, s. 349; Wall, 1997 , s. 291). Tässä tutkimuksessa tarkastelun keskiössä ovat kielitutkinnon luokkahuonevaikutukset, kun haastateltavina ovat kielitutkintoa valmistelleet asiantuntijat ja tutkintoon valmentaneet opettajat. Useat haastattelukysymykset käsittelevät kielitutkinnon vaikutuksia opetukseen ja oppimiseen, mutta haastatteluissa nousi esille myös näkökulmia, joissa tutkinnon vaikutukset ulottuivat luokkahuonetta laajemmalle. Tutkimusaihe ei siis rajaudu yksistään washback-ilmiöön, vaikka se onkin tässä keskiössä.

Kielitutkintojen vaikutuksia on tutkittu varsin laajasti englannin kielen merkittävien tutkintojen osalta (mm. Cheng \& Curtis, 2004). Kielitutkintojen vaikutuksia kartoittaneissa tutkimuksissa on noussut esille tutkinnon sekä toivottuja että ei-toivottuja vaikutuksia. Positiivisia vaikutuksia ovat olleet tavoitteiden selkeys, selkeä edistyminen kielitaidossa ja korkea motivaatio (Loumbourdi, 2014, s. 139-144; Moore, Stroupe \& Mahony, 2009, s. 324). Loumbourdin tutkimuksessa opettajat arvioivat myös tutkintoon valmistautumisen vaikuttavan hyvien opiskelukäytänteiden omaksumiseen ja opiskelijat huomasivat englanninkielisten tekstien lukemisen lisääntyneen (2014, s. 140).

Negatiivisina tutkinnon tuomina vaikutuksina mainitaan se, että kielitutkintoon valmentavilla kursseilla opetus keskittyy voimakkaasti tutkinnossa tarvittaviin, joskus hyvin kapea-alaisiin taitoihin, mikä saattaa tukahduttaa luovuutta ja tehdä kurssista yksitoikkoisen (Moore ym., 2009, s. 324). Loumbourdin (2014) tutkimuksessa korostui ilmapiirin stressaavuus: kun tutkintoon valmentavaa koulutusta antaa yksityinen kielikoulu, paineet tutkinnossa menestymiselle ovat kovat. Sekä opiskelijat että opettajat kertoivat testiin valmistautumisen olevan stressaavaa (Loumbourdi, 2014, s. 139 ja 142). Kurssille osallistuminen saattaa luoda epärealistisia odotuksia tutkinnossa menestymisestä (Moore ym., 2009, s. 324). Watanabe (2004, s. 141) kiinnitti huomiota japanilaisia valmennuskursseja tutkiessaan siihen, että yksilölliset opettajakohtaiset erot ovat suuria: toisilla opettajilla testiin valmistautuminen aiheutti negatiivista vaikutusta, esimerkiksi epäsuotuisien opetusmenetelmien valintaa. Toisilla ei negatiivista vaikutusta ollut. 
Menken (2007) on tarkastellut kielitutkintojen vaikutuksia luokkahuonetta laajemmin, ja hän väittää, että tutkinnoilla on harvoin niitä vaikutuksia, joita päättäjät ovat tavoitelleet. USA:ssa astui vuonna 2001 voimaan laki, joka velvoittaa koulutuksen järjestäjiä testaamaan englanti toisena kielenä -oppilaat vuosittain. Vaikka testejä perusteltiin kielenopetuksen tukitoimien tehostamisella, seurauksena onkin ollut ei-toivottuja muutoksia opetuksen sisällössä: opetus keskittyy tutkinnossa vaadittaviin taitoihin, ei siihen, mitä kielenoppijat itse asiassa tarvitsevat (Menken, 2007, s. 407-408). Saville (2013, s. 4) arvioi, että monien laajojen englannin kielen tutkintojen (mm. IELTS ja TOEFL) validiteetti on hyvä, mutta niiden tuloksia käytetään sellaisiin tarkoituksiin, joihin niitä ei ole tarkoitettu.

Kielitutkinnon vaikutukset eivät siis aina johdu ainakaan pelkästään tutkinnon ominaisuuksista vaan myös siitä, millä tavalla tutkinnon kanssa tekemisissä olevat henkilöt suhtautuvat tutkintoon. Opettajat ovat olleet avainasemassa, kun he ovat valmentaneet kielenoppijoita Dipaki-tutkintoa varten. Siksi opettajien näkemykset tutkinnosta valaisevat tutkinnon vaikutuksia. Haastattelemieni asiantuntijoiden rooli kielitutkinnon luomisvaiheessa oli merkittävä. Vaikka työryhmän työskentely oli päättynyt jo vuosia aiemmin, he olivat joko työtehtäviensä kautta tai muista syistä seuranneet kielitutkintoon valmentautumista ja tutkinnon toteutusta myös tämän alkuvaiheen jälkeen. Näin myös heidän arvionsa tutkinnolle asetettujen tavoitteiden saavuttamisesta ovat merkityksellisiä.

Van Avermaet ja Pulinx (2014, s. 384-385) esittävät kriittisen näkökulman Belgian ns. integraatiotutkintoon (integration test) flaaminkielisellä alueella. Integraatiokursseilla oleville tutkinto antoi toivoa. Monet kursseille osallistuneet uskoivat, että tutkinnon suorittaminen auttaa heitä löytämään töitä.
Vuosi koulutuksen ja tutkinnon jälkeen mielipiteet jakautuivat voimakkaasti: Ne, jotka olivat löytäneet työtä, näkivät tutkinnon vaikutuksen positiivisena. Ne, jotka eivät olleet työllistyneet, eivät nähneet kielitaitoaan eivätkä kielitutkintotodistusta hyödyllisenä (Van Avermaet \& Pulinx, 2014, s. 385). Työnantajat eivät tunteneet integraatiotutkintoa lainkaan, vaan heidän rekrytointipäätöksiään säätelivät taloudelliset tekijät. Työnvälitystoimistojen virkailijoiden mielestä integraatiokoulutuksen todistuksella tai muulla flaamin kielen todistuksella oli vain vähän arvoa. Ainoat, jotka näkivät kielitutkinnolla jonkin verran merkitystä, olivat opettajat (Van Avermaet \& Pulinx, 2014, s. 385). Merkittävää tässä ovat eri toimijoiden hyvinkin vastakkaiset näkemykset samasta ilmiöstä ja myös se yksilökohtaisuus, joka väritti tutkinnon suorittaneiden mielipiteitä: työtä saaneet suhtautuivat positiivisesti, työttömäksi jääneet negatiivisesti. Tämän tutkimuksen perusteella on siis oletettavaa, että opettajat suhtautuvat tutkintoon myönteisesti ja näkevät sillä mahdollisesti jopa sellaisia myönteisiä vaikutuksia, joita kielenoppijat eivät näe.

Kielitutkinnon olemassaolo ja siihen valmistautuminen voivat vaikuttaa sekä kielen opetukseen ja oppimiseen että myös asenteisiin näitä kohtaan. Testillä voi olla oppimiseen sekä myönteisiä että myös kielteisiä vaikutuksia, myönteiset vaikutukset voivat olla joko tavoiteltuja tai tavoittelematta saavutettuja, ja testin vaikutukset voivat olla lieviä tai voimakkaita. Lievällä vaikutuksella voidaan tarkoittaa tilannetta, jossa testin merkitys on vähäinen kaikille kielen opiskelijoille, tai sellaista tilannetta, jossa testillä ei ole lainkaan merkitystä joillekin, mutta harvoille sillä on voimakas vaikutus (Watanabe, 2004, s. 20-21). Tutkinnon suorittaminen ja näin kielitaidon osoittaminen voi olla tapa todistaa "moraalinen kansalaisuus" (Van Avermaet \& Pulinx, 2014, s. 377). Tällainen todistustaak- 
ka vaikutti varmasti myös ainakin joidenkin inkeriläisten mielessä, kun he olivat menossa suorittamaan Dipaki-tutkintoa.

Tutkimuksen teoreettisena viitekehyksenä on Henrichsenin (1989) malli innovaatioiden käyttöönotosta englannin kielen opetuksessa (kaavio 1). Mallissa tarkasteltava aika jaetaan innovaatiota edeltävään aikaan, käyttöönot- toprosessiin ja seurauksiin. Tässä tutkimuksessa innovaatio, jolla opetukseen ja opiskeluun on pyritty vaikuttamaan, on kielitutkinto. Tutkintoa edeltävästä ajasta on olemassa asiakirjoja (Työministeriö, 2003a; 2003b) ja välillisesti sain tuosta ajasta tietoa jälkikäteen tehtyjen henkilöhaastattelujen kautta.

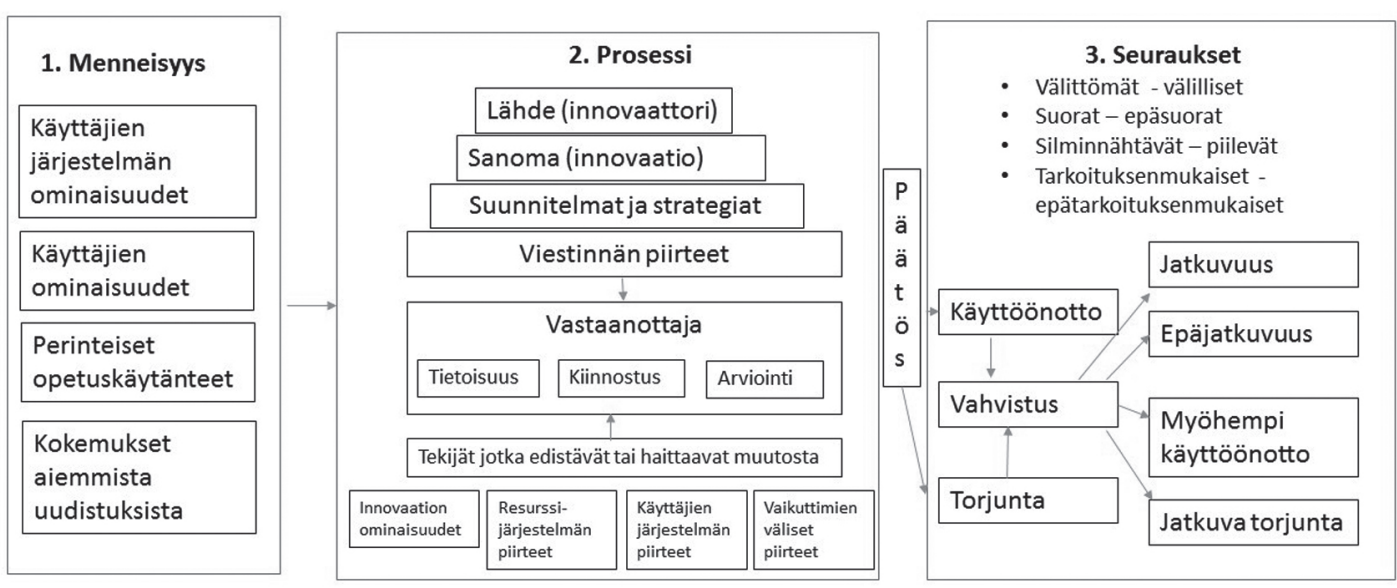

Kaavio 1. Henrichsenin malli innovaatioiden käyttöönotosta opetuksessa (Henrichsen, 1989, s. 80, myös Wall \& Horák, 2008, s. 8).

Henrichsenin mallissa prosessivaiheen kuvauksessa kiinnitetään huomiota innovaation piirteisiin ja innovaatioon liittyvään viestintään, vastaanottajan, tässä tapauksessa opettajan tietoisuuteen, kiinnostukseen ja arvioon sekä muutosta edistäviin ja estäviin tekijöihin. Tämän prosessin myötä vastaanottaja tekee päätöksen joko ottaa innovaatio käyttöön tai torjua se. Muutos voi olla pysyvä tai tilapäinen. Muutos voi olla välitön tai viivästynyt, suora tai epäsuora, näkyvä tai piilevä, tarkoituksenmukainen tai epätarkoituksenmukainen (Kaavio 1).

Näistä muutoksista etsin todisteita opettajien haastatteluista. Mikäli opettajat mainitsevat tutkinnon vaikutuksina sellaisia asioita, joita tutkinnon käyttöönottovaiheessa asetettiin tavoitteeksi, on tutkinto ollut innovaatio ja aiheuttanut washback-vaikutusta. Tutkinnon ominaisuuksilla ja opetuksella on tällöin yhteys (Messick, 1996, s. 247).

\section{TUTKIMUKSEN TOTEUTUS}

Olen kerännyt tutkimusaineiston kyselyn ja teemahaastatteluiden avulla. Kielitutkinnon valmisteluvaiheessa vuonna 2003 perustettiin kymmenen hengen työryhmä, jonka tehtävänä oli mm. kielitutkinnon perusteiden laatiminen, tutkinnon toimeenpano, tutkinnon laadunvalvontaan ja kehittämiseen liittyvät asiat sekä kielitutkinnon mahdollisten muuttoon liittyvien vaikutusten seuranta (Työministeriö, 2003b). Työryhmä toimi Suomessa. Haastattelin kolmea tämän työryhmän jäsentä. Olen toiminut tässä kielitutkinnossa 
tutkintosuoritusten arvioijana alusta alkaen. Tätä kautta osa tutkinnon taustasta ja toimintatavoista oli minulla jo tiedossa ja tiesin, ketkä työryhmän jäsenet olivat olleet kaikkein eniten tekemisissä tutkinnon laatimisessa, toimeenpanossa ja kehittämisessä. Nämä haastattelut toteutin kesä-marraskuussa 2015 Helsingissä ja Tampereella. Haastattelun teemoina olivat Dipaki-tutkinnon tausta, sisältö ja vaikutukset.

Opettajia oli lukuvuonna 2015-2016 kaikkiaan kahdeksan, joista kolme Pietarissa ja viisi Petroskoissa. Opettajille suunnatulla kyselyllä keräsin taustatietoa mm. ryhmien koosta ja kielitaidon tasosta kurssin aikana, käytetyistä oppimateriaaleista ja myös opettajien käsityksistä (kyselyiden laatimisesta Vehkalahti, 2014). Kyselyyn vastasi viisi opettajaa. Kyselyn ja myös paluumuuttovalmennuksen koordinaattorin haastattelun avulla sain taustatietoa, jota pystyin hyödyntämään varsinaista opettajien haastattelurunkoa laatiessani. Hioin haastattelurunkoa saamani palautteen perusteella. Toteutin kyselyn internetin välityksellä syyskuussa 2015 ja opettajien haastattelut Kotkassa lokakuussa 2015. Haastattelua varten tavoitin koko tarkastelussa olevan ryhmän, kahdeksan opettajaa. Haastatteluaineistoa kertyi yhteensä 283 minuuttia. Keskeiset aihealueet, joista halusin haastattelun avulla saada opettajilta tietoa, olivat kielitutkinnon vaikutukset opetuksen sisältöön, opetusmenetelmiin, ilmapiiriin ja opiskelijoiden asenteisiin kurssilla. Käytin luomaani haastattelurunkoa, jota mukailin keskustelun luontevuuden säilyttämiseksi. Haastatellut opettajat olivat kaikki toimineet opettajina jo vuosia (7-30 vuotta). Kun kysyin heidän äidinkieltään, useimmat ottivat samalla identiteetin esille: lähes kaikki nimesivät venäjän äidinkielekseen, mutta viisi kahdeksasta nosti äidinkielen yhteydessä esille inkeriläisen taustan.

Kun opettaja miettii yksittäistä pedagogista ratkaisuaan, miten hän jonkin asian opettaa, ratkaisun taustalla on usein monia tekijöitä (esim. Watanabe, 2004, s. 141) eikä hän välttämättä ole tietoinen niistä kaikista. Valintaa voi ohjata oppimateriaalin laatu ja saatavuus, tilaresurssit ja opetusvälineet, käytettävissä oleva aika ja opiskelijaryhmän piirteet. Opettajalla voi olla vaikkapa hyviä kokemuksia joistakin tehtävätyypeistä ja siten mieltymys tietynlaisiin pedagogisiin ratkaisuihin. Lisäksi haastattelutilanne vaikuttaa siihen, kuinka opettaja muotoilee sanomansa. Hänellä saattaa olla oletuksia toivotuista tai "oikeista" vastauksista, ja haastattelijan asettamat kysymykset ohjaavat keskustelun kulkua. Edellä esitetyt ja mahdollisesti muut seikat, joita tutkija ei haastattelutilanteessa edes voi ennakoida, vaikuttavat haastattelun kulkuun ja siten aineiston muodostumiseen. Tärkeää on kuitenkin paikantaa oma rooli tutkijana (Rantala, 2006, s. 228-229, opettajien haastatteluista myös Wall ja Horák, 2006, s. 20). Kun menin Kotkaan haastattelemaan opettajia heidän täydennyskoulutuksensa yhteydessä, esittelin itseni kielentutkijana ja kerroin lyhyesti tutkimuksen ja haastattelun aiheen. Korostin sitä, että olin kiinnostunut heidän ajatuksistaan ja käsityksistään, ja myös sitä, että oikeita vastauksia ei ole.

Litteroin aineiston karkeasti. Tarkastelussa ovat sanatason ilmiöt, joten tätä tarkempi litteraatio ei ollut tarpeen. Analyysivaiheen alussa poimin aineistosta osiot, joissa haastateltava puhuu tutkinnon vaikutuksista. Sosiaalista toimintaa tarkastellaan tässä diskurssianalyysin tapaan tutkimuksen kannalta olennaisissa konteksteissa (esim. Pietikäinen, 2012, s. 418; Pietikäinen \& Mäntynen, 2009, s. 29). Tutkimuksessani kaikkein ilmeisimpänä kontekstina on haastattelutilanne, jossa opettajat vuorollaan ovat. Lisäksi opettajien puheenvuoroissa välittyivät tiiviit suhteet kollegoihin: he olivat tuolloin yhdessä koulutuspäivillä Kotkassa, ja samoja teemoja oli mahdollisesti käsitelty kollegoiden kesken ja 
myös aiemmissa koulutustilaisuuksissa. Puheessa kuului myös viittauksia venäläiseen koulumaailmaan, Suomeen ja suomalaisuuteen. Nämä ovat konteksteja, joihin tarkastellut keskustelut linkittyvät. Asiantuntijoiden haastatteluja tarkasteltaessa on huomioitava aikaperspektiivi. Esitän kysymyksiä siitä, mitä kielitutkinnolla on sen syntyvaiheessa, 13 vuotta aiemmin tavoiteltu. Samalla haastateltavat esittävät arvionsa siitä, miten nuo tavoitteet ovat toteutuneet.

\section{MITÄ DIPAKI- KIELITUTKINNOLLA TAVOITELTIIN JA MITÄ SAAVUTETTIIN?}

Pureudun tarkastelemaani aineistoon sisällönanalyysin keinoin eritellen, yhtäläisyyksiä ja eroja etsien (esim. Tuomi \& Sarajärvi, 2002, s. 105). Esittelen aluksi Dipaki-kielitutkinnolle asetettuja tavoitteita tutkintoon liittyvien asiakirjojen (Työministeriö, 2003a; 2003b) ja työryhmän asiantuntijoiden haastattelujen pohjalta. Tämän jälkeen tarkastelen tutkinnon vaikutuksia sekä asiantuntijoiden että myös opettajien puheessa. Haastatellut opettajat on yksilöity juoksevalla numerolla 1-8, esimerkiksi $\mathrm{O} 2$ on opettaja numero kaksi. Numerojärjestys on satunnainen. A tarkoittaa kielitutkintotyöryhmän asiantuntijajäsentä, H haastattelijaa.

Opettajien haastatteluissa kielitutkinnosta nousi esille niin myönteisiä kuin myös kielteisiä vaikutuksia opetukseen ja oppimiseen. Keskeisimmät vaikutukset koskivat opetuksen sisältöä, tehtävätyyppejä ja opiskelijoiden motivaatiota. Opettajat nostivat usein esille myös Suomeen kotoutumisen ja tutkinnon virallisen aseman. Vertaan opettajien kuvaamia vaikutuksia työryhmän jäsenten kertomaan siitä, mitä tutkinnolla alun perin tavoiteltiin. Tarkastelen vaikutuksia myös positiivisuusnegatiivisuus-akselilla.

\subsection{Tavoitellut vaikutukset}

Kielitutkinnon perusteissa tutkinnon tarkoitukseksi määritellään sen testaaminen, osaako testattava henkilö viestiä suomen tai ruotsin kielellä ja riittääkö testattavan kielitaito auttavaan selviytymiseen suomen kielellä Suomessa (Työministeriö, 2003a). Kielitutkintoon liittyvän ulkomaalaislain toimeenpanoa ja toteuttamista varten perustetulle työryhmälle asetettiin seuraavat tehtävät:

- inkerinsuomalaisten kielitestin perusteiden käsittely

- kielitestin toimeenpanoon liittyvät kysymykset

- kielitestiin liittyvän koulutuksen koordinointi

- testijärjestelmän laadunvalvontaan, kehittämistoimintaan ja oikeusturvakysymyksiin liittyvät asiat

- kielitestijärjestelmän toteuttamisen yleinen seuranta, yhteensovittaminen ja kehittäminen sekä siihen liittyvien aloitteiden tekeminen

- kielitestien mahdollisten muuttoon liittyvien vaikutusten seuranta

- paluumuuttajien asuntotilanteen yleinen seuranta (Työministeriö, 2003b).

Tehtävälistalla olivat sekä kielitutkinnon kehittäminen ja toimeenpano että myös kielitutkintoon liittyvän koulutuksen koordinointi. Sitä, mihin suuntaan tutkintoa tai koulutusta oli tarkoitus kehittää, ei tässä työryhmän asettamisasiakirjassa tarkemmin määritelty.

Kun kielitutkintoa 1990-luvun loppupuoliskolla suunniteltiin, käytiin mediassa värikästä keskustelua inkeriläisten paluumuutosta ja siihen liittyvistä ilmiöistä. Tuolloin keskustelussa inkeriläisten kielitutkinnon tarpeellisuudesta vedottiin inkeriläisten suo- 
malaiseen identiteettiin ja toisaalta auktoriteetteihin, haluttiin ehkäistä syrjäytymisestä ja viitattiin siihen, mikä on riittävä kielitaito (Martikainen, 2016). Vuonna 2015 tekemissäni haastatteluissa asiantuntijat viittasivat mediassa käytyyn keskusteluun, mutta heidän puheessaan oli varsin vähän yhtymäkohtia keskustelun sisältöön. Yksi haastatelluista (A2) viittasi julkiseen keskusteluun siitä, että kielitutkintoa pidettiin aiemmin käytössä ollutta haastattelua tiukempana tapana arvioida oleskeluluvan hakijoiden kielitaitoa. Tutkintotyöryhmän jäsenet korostivat kuitenkin kielitaidon arvoa sinänsä, eivät niinkään kielitutkinnon valikoivaa merkitystä kielitaidottomien erottelijana.

Kaikki haastattelemani asiantuntijat mainitsivat kielitutkinnon tavoitteeksi selviytymiskielitaidon kehittämisen erityisesti puhumisen osalta. Sekä selviytymiskielitaito että myös puhetaidon korostuminen pohjautuvat kielitutkinnon perusteisiin (Työministeriö, 2003a). Asiantuntijat nostivat esille myös kielitutkinnon keinona testata luotettavalla tavalla, osaavatko inkeriläisstatuksella oleskelulupaa hakevat henkilöt suomea, kuten laissa vuodesta 2003 alkaen edellytettiin (esimerkit 1 ja 2).

A3: Pitäisi sitten jollakin tavalla tarkistaa että he osaa suomea riittävästi voidaksensa tulla toimeen ja integroitua, kotoutua Suomeen.

A2: Haluttiin että on tämmönen mittari ja ihmisille motivaatio opiskella sitä kieltä että he sitten saavat todistuksen virallisen arvioin siitä kielitaidosta.

Näissäkään repliikeissä ei kielitaidon arviointi ole tavoite sinänsä vaan kotoutumiseen riittävän kielitaidon tarkistaminen esimerkissä 1 ja opiskelun motivointitavoite esimerkissä 2. Yhtenä tavoitteena kielitutkinnon käyttöönotossa oli ennen kielitutkintoa tapahtuvan opetuksen kehittäminen, kuten työryhmän tehtäväksi oli asetettu (esimerkit 3 ja 4):

A3: Myöskin tämä opetus täytyy, sitä pitää kehittää. Että tämä nuorempi sukupolvi, joka olis kiinnostunut, että heillä sitten kehittyisi suomen kielen taito, tällaisen motivoivan ja käytäntöön orientoituvan opetuksen avulla.

A3: Ja siksi tämä tutkinto sitten tämän tietynlaisen laadun kai sen voi sanoa että se oli tietynlainen ajatus laadun varmistamisesta, tarkistuksesta että onko sitä taitoa riittävästi.

Opetuksen kehittämisessä ja kielitutkinnossa nähtiin myös kielen opiskelua motivoiva merkitys. Näin opetuksen laatu, opiskelumotivaatio, kielitaito ja lopulta Suomeen kotoutuminen nivoutuvat yhden prosessin osasiksi.

\subsection{Opetuksen sisältö ja tehtävätyypit}

Kun kielitutkintoa suunniteltiin, siihen liittyi pyrkimyksiä vaikuttaa opetukseen, lisätä motivaatiota ja edistää näin suomen kielen oppimista. Kaikki haastattelemani työryhmän jäsenet arvioivat tämän tavoitteen toteutuneen (esimerkit 5 ja 6).

A3: Kyllä se on tehostanut kovasti paluumuuttovalmennusta, kielenopetuksen ja varmaan muiltakin osin. 
(6)

A1: No ainakin mitä nyt sitten tavoitettiin niin oli se että tämä (.) Venäjällä ja (.) pääasiassa Venäjällä annettavaa valmennusvalmennuskoulutus niin se kyllä on erittäin paljon rybdistäytynyt.

Opettajien mielestä kielitutkinto on vaikuttanut merkittävästi opetuksessa käsiteltävien aiheiden valintaan. Opetuksessa käsiteltiin niitä teemoja, joita tutkinnossa vaadittiin. Useimmat totesivat, että aiheet ovat niitä, joita muutenkin tarvitaan (esimerkki 7):

\section{(7)}

O6: Eli itsestään pubuminen ja perheestä ja kaikki ne aibeet joita oikeastaan tarvitaan tavallisessa elämässä ja myös Dipakissa.

Puheenvuoroissa kuului voimakas sitoutuminen opetukseen, vastuu opiskelijoista ja siitä, että he suorittavat kielitutkinnon hyväksytysti, kuten seuraava haastateltu (esimerkki 8):

\section{(8)}

O7: Mun toiminta riippuu sataprosenttisesti tästä asiasta, että heidän edessä̈n on tutkinto.

Opettajat uskoivat tutkinnossa vaadittujen sisältöjen mielekkyyteen, eikä Menkenin (2007, s. 407-408) havaitsemaa negatiivista vaikutusta, pelkkiin tutkinnossa vaadittujen asioiden opettamista, noussut esille opettajien puheessa.

Asiantuntijajäsenet nostivat voimakkaasti tavoitteeksi puhetaidon kehittämisen. Opettajien haastattelujen perusteella tutkinnon rakenne ja arviointitapa ovat vaikuttaneet opetuskäytäntöihin. Kaikki haastatellut opettajat mainitsivat puheharjoitukset tärkeänä tehtävätyyppinä. He olivat sisäistäneet myös selviytymiskielitaidon vaatimustason (esimerkki 9).
H: Millä tavalla tää kielitutkinto vaikuttaa sinun opetukseen?

O4: Minä tiedän että Dipaki-tutkinnossa on neljä tehtävää ja tärkein on tämä pubuminen ja minä ymmärrän, että minun pitää opettaa niin, että ibminen puhuisi eikä hän ajattelisi paljon siitä että mikäpääte on tässä sanassa ja mitä jos minä sanon väärin jotain.

Opetuksessa painotettiin siis sellaista, mikä oli tutkintosuorituksen arvioinnissa oleellista: suomen kielellä viestiminen (Työministeriö, 2003a). Tarkkuutta ei selviytymiskielitaidon tasolla vaadita. Samoin kaikki opettajat nostivat tavalla tai toisella esille tutkinnon vaikutuksen kielenopetuksen tehtävätyyppien valintaan. Tutkinnon tehtävätyyppejä harjoiteltiin kurssilla, ja opettajat suhtautuivat tähän neutraalisti tai positiivisesti. Eräs opettaja (O4) totesi, että hän käyttäisi samantyyppisiä tehtäviä, vaikka tutkintoa ei olisikaan, koska hän oli huomannut ne toimiviksi.

Myös testitekniikkaa harjoiteltiin ja valmistauduttiin tutkinnossa toimimiseen (esimerkit 10 ja 11).

O1: Tehdään näin että ihan loppuvaiheessa otetaan joku teema ja sitten jollakin on kello ja sinulla on- yhdellä henkilöllä on viistoista sekuntia aikaa vastaamaan kysymykseen. Että vähän ollaan testitilaisundessa, harjoitellaan nopeutta.

O6: Mä sitten itse ajattelin että täytyy aina muistaa niille sanoa että jotenkin abstrakoitua täytyy tässä testissä. Usein ne kysymykset eivät kohdistu sinuun henkilökobtaisesti mutta kuvittele että sinä olet se joka - 
Opettajien puheessa kielitutkintoa pidettiin myös hyvänä mahdollisuutena tottua testaamiseen ja antaa näyttöä osaamisesta. Tutkinnolla oli siis itseisarvoa, ei pelkkä välinearvo Suomen oleskeluluvan hakuprosessissa.

Kun tutkinnolle asetettuja tavoitteita ja sen vaikutuksia vertaillaan Henrichsenin (1989) mallin mukaisesti, vaikuttaa siltä, että innovaation, kielitutkinnon käyttöönottoprosessi on onnistunut opetusvaikutusten osalta: tutkinnon käyttöönoton myötä opetuksessa on saavutettu sen suuntaisia muutoksia, joita kielitutkinnon perusteissa kielitaidolta edellytetään ja jota kielitutkintotyöryhmän jäsenet toivoivat. Haastattelujen perusteella voisi väittää, että tutkinnon vaikutus opetuksen sisältöön ja menetelmiin on ollut varsin voimakas. Kansainvälisissä tutkimuksissa on kuitenkin havaittu, että kielitutkinnoilla on vaikutusta opetuksen sisältöön, ei niinkään menetelmiin (esim. Cheng, 2004, s. 164). Paluumuuttovalmennuksessa kielitutkinto tuskin on yksin yltänyt tähän opiskelijaa aktivoivien opetusmenetelmien lisääntymiseen, vaan vaikutus on todennäköisesti syntynyt yhdessä opettajakoulutuksen kanssa. Valmennuskurssien opettajilla on vuosien ajan ollut opettajakoulutusta, oppimateriaalien jakamista ja muuta tukea (Mielonen, 2014; 2016), mikä on varmasti osaltaan vaikuttanut opetuskäytänteisiin. Kielitutkinto yhdessä opettajien täydennyskoulutuksen kanssa on ollut innovaatio, joka tämän muutoksen on saanut aikaan. Lisäksi opettajien ammattiidentiteetti on viime vuosikymmenet ollut Venäjällä voimakkaassa murroksessa (opettajakeskeisen ja oppijakeskeisen opetusmenetelmän murroksesta Pöyhönen, 2003), ja näillä Suomen viranomaisten järjestämillä toimilla on nähtävästi pystytty tukemaan opettajia kohti uusia toimintatapoja ja viestinnällisempää kielenopetusta.

\subsection{Motivaatio}

Yksi keskeinen kielitutkinnolle asetettu tavoite oli opetuksen "ryhdistäminen" (A1) ja opiskelijoiden motivointi. Opettajien haastatteluissa myönteisistä vaikutuksista kaikkein useimmin nostettiin esille opiskelijoiden motivaatio ja ahkeruus (esimerkki 12):

O3: Kurssin lopussa täytyy olla testi, koska jos sitä ei ole, opiskelija ei ole niin motivoitu.

Tämä nousi esille lähes kaikkien opettajien puheessa. Yksi opettaja kuvasi tutkinnon kannustavaa ja samalla pakottavaa vaikutusta (esimerkki 13):

\section{(13)}

O7: Jos mulla ei olisi tällaisia (.) ohjaksia, - jonka avulla mä voisin sekä kannustaa että pakottaa heitä opiskelemaan, siis mä saisin ihan erilainen, erilaisia, tuloksia olen varma.

Tämä tulos on yhdenmukainen kansainvälisten washback-tutkimusten kanssa. Muun muassa Loumbourdin (2014, s. 139-144) tutkimuksessa opettajat arvioivat, että kielitutkinto motivoi opiskelijoita ja ohjaa heitä kehittelemään hyviä opiskelukäytäntöjä.

Belgialaistutkimuksessa monet tahot pitivät kielitutkinnon merkitystä integraatiossa vähäisenä, mutta opettajat näkivät sillä jonkin verran merkitystä (Van Avermaet \& Pulinx, 2014, s. 377). Tutkimuksessani korostui valmennuskurssien opettajien myönteinen suhtautuminen kielitutkintoon. He pitivät sitä hyödyllisenä ja korostivat sen motivoivuutta sekä suomen kielen opiskelun kannalta että myös laajemmin. Oman työnsä kannalta opettajat nostivat esille sen, että kielitutkinto asettaa selkeät tavoitteet. Jo valmennuskurssin alkaessa sekä opettajilla että myös opiske- 
lijoilla on tiedossa, millaista kielitaitoa tutkinnossa vaaditaan. Opettajat pitivät myös tätä myönteisenä asiana.

\subsection{Suomeen muuttaminen}

Inkeriläisten kielitutkinto on vahvasti sidoksissa Suomeen muuttamiseen, sillä sen suorittamista vaadittiin juuri Suomen oleskelulupaa varten. Tämä kuuluu sekä tutkintoa suunnitelleiden asiantuntijoiden että myös opettajien puheessa (esimerkit 14 ja 15).

H: Mikä sinun mielestäsi on tämän tutkinnon keskeisin merkitys?

A1: Minusta se on se merkitys siinä, että nämä inkeriläiset jotka haluavat asua Suomessa, ja joista kaikilla ei enää äidinkielenä ole se vanha suomen kieli, että he sitten selviytyvät käytännön asioista Suomessa, eli pystyvät elämään tässä meidän yhteiskunnassa.

A1: Ja sitten toisena jos ajattelis niin kyllä mä näkisin että vaikka tätä tutkintoa pidetään aika vaatimattomana niin kyllä se on myöskin parantanut näiden tänne muuttaneiden mabdollisuuksia kotoutua paremmin kuin ehkä ilman tätä kielitutkintoa.

Myös opettajat vetosivat Suomessa asuessa tarvittaviin taitoihin, siihen että kielitaito yleensä kehittyy, aiheet ovat hyödyllisiä, kielenoppija osaa puhua suomea ja hoitaa omia asioitaan suomeksi (esimerkki 16).

O6: No oikeastaan ihan selvä että ne jotka muuttaa Suomeen, tarvitsee suomea. Eli oikeastaan se tutkinto ei ole ainoa, loppupiste mihin pyritään mutta totta kai pyritään saamaan kielitaito sille tasolle että tulevat
Suomen asukkaat, muuttajat pärjäävät ihan tavallisissa arkioloissa hoitamaan omat asiansa täällä Suomessa.

Monet opettajat nostivat esille opettajan vastuun opiskelijoiden onnistumisesta tutkinnossa ja myös oman asemansa Suomeenmuuton valmentajina. Eräs opettaja totesi seuraavasti (esimerkki 17):

H: Mitä ajatuksia tämä kielitutkinto herättää sinussa tällä hetkellä?

O8: No minä sanoisin että minusta kaikki suomen kielen opettajat ovat vastuullisia siitä että miten oppilas menestyy ja suorittaako hän tämän tutkinnon.

Tämä vaikuttaa kovin voimakkaalta väitteeltä, siltä että opiskelijalla ei olisi vastuuta. Tämä voi heijastella aiemmin mainitsemaani opettajan roolin murroskohtaa Venäjällä (Pöyhönen, 2003). Voimakas opettajan vastuuta korostava kannanotto voi viitata tähän keskusteluun. Monissa puheenvuoroissa tutkinto nähtiin porttina Suomeen tai todisteena siitä, että henkilö pärjää kielen puolesta Suomessa (esimerkit 18 ja 19):

O3: Minä luulen tämä tutkinto auttaa ibmisiä (.) kotoutumaan Suomeen.

O1: Se (tutkinto) olisi niin kuin takuuna että hän pystyy pärjäämään uudessa kotimaassa.

Seuraavasta esimerkistä käy ilmi opettajien puheenvuoroissa yleinen suhtautumistapa. He opettavat asiaa tutkintoa varten, mutta uskovat, että siitä on hyötyä myös tutkinnon jälkeen (esimerkki 20). 
(20)

O1: No just esimerkiksi tekstin ymmärtämisen osa jossa mä tiedän että voi tulla ne opasteet ja kyltit. Just kielitutkintoa varten opetan mutta tulevaisuudessa ne tarvitsevat niitä todellisessa elämässä jos muuttavat tänne.

Yksi opettaja totesi, että suomalaisuutta on vaikea mitata muulla tavoin kuin kielitaidon kautta. Hänen mukaansa silloin, kun hakee oleskelulupaa inkeriläisstatuksella, "voidaan odottaa että henkilö osaa vähän suomea" (O5). Tämä oli selkeä viittaus keskusteluun identiteetistä, siitä kuka on inkeriläinen, mitä inkeriläisyys on ja mikä osuus kielitaidolla siinä on (inkeriläisten kansallisuuskäsityksistä Davydova, 2002, s. 156-159).

\subsection{Stressivaikutus}

Tutkinnon kielteiset vaikutukset tulivat keskustelussa esille vain, kun kysyin niistä erikseen; spontaanisti ne eivät nousseet esille. Opettajien nimeämiä negatiivisia vaikutuksia olivat kielenoppijoiden hermostuneisuus ja stressaantuminen. Jotkut opettajat sanoivat, että he tietävät tapauksia, joissa tutkinnon suorittaja on saanut hylätyn arvosanan tutkinnossa jännittämisen vuoksi. Menken (2007, s. 410-411) ehdottaa, että olisi hyödyllistä etsiä monipuolisempia tapoja antaa näyttöä kielitaidoista silloin, kun tuloksia käytetään merkittävien päätösten tekemiseen. Haastattelemani opettajat eivät ottaneet tätä esille. Sen sijaan jotkut suhtautuivat jännitykseen jonkinlaisena luonnollisena ilmiönä (esimerkit 21-23).

O5: Kyllä se jonkin verran hermostuttaa että aikaa on vähän ja miten mä selviydyn.
O5: No, kyllä sillä on jotakin merkitystä mutta vaikuttaa vain muutamiin. On sellaisia ibmisiä joita elämä periaatteessa pelottaa.

O7: Kyllä melkein kaikki ovat hermostuneita.

Vastauksissa 21 ja 22 käytettiin stressin intensiteetin määritteinä jonkin verran ja vaikuttaa vain muutamiin, ei siis paljon tai moniin. Näin maltillisin ilmaisuin opettajat kuvailivat stressivaikutusta. Yksi opettaja (O7) puhui opiskelijoiden stressistä enemmän ja sanoi melkein kaikkien olevan hermostuneita. Hän myös kertoi tapauksista, että opiskelija ei olisi suorittanut tutkintoa hyväksytysti, vaikka tuntitilanteessa kielitaito oli opettajan mielestä ollut riittävä. Pääsääntöisesti opiskelijoiden kokemaa stressiä ei korostettu eikä sitä nostettu opettajien aloitteesta esille.

Opettajat kuvailivat tutkinnon luomaa painetta suunnitella opetus systemaattisesti niin, että kaikki aihealueet ja kaikki tehtävätyypit tulevat tutuksi. Useat suhtautuivat tähän vaativuuteen kuitenkin neutraalisti tai myönteisesti. He totesivat, että tutkinnon olemassaolo luo raamit ja asettaa tavoitteet kielenoppimiselle ja -opetukselle. Vain yksi totesi, että tutkinnon myötä hän käyttää toivomaansa enemmän aikaa kirjoittamisen opetukseen ja joutuu luetun ymmärtämisessä käyttämään tekstejä, jotka eivät ole hauskoja. Tässä toistuu Watanaben (2004, s. 141) esille nostama ilmiö: joillakin opettajilla tutkinto aiheutti epäsuotuisien tehtävätyyppien valintaa. Näin ei kuitenkaan käy kaikkien opettajien kohdalla. 


\section{POHDINTA}

Kielitutkintotyöryhmän jäsenten mukaan Dipaki-tutkinnolla tavoiteltiin seuraavia opetuksen ja oppimiseen liittyviä vaikutuksia: paluumuuttovalmennuksen opetuksen kehittäminen erityisesti kommunikatiiviseen suuntaan, tutkintoon tulijoiden motivointi ja täten kielitaidon kehittäminen ja Suomeen kotoutumisen edistäminen. Opettajien haastattelujen perusteella voi sanoa, että tämä kielitutkinto on vaikuttanut voimakkaasti opettajien toimintaan valmennuskurssilla. Opettajat suhtautuivat tutkintoon päöosin myönteisesti ja kokivat, että se tuki heidän työtään. Ilman tutkinnon asettamaa osaamisen pakkoa opiskelijat olisivat olleet vähemmän motivoituneita. Tutkinto asetti myös selkeät tavoitteet ja raamit opetuksen sisällölle ja oppimiselle. Opettajat painottivat opetuksessaan puhumista ja perustelivat sitä osin tutkinnon vaatimuksilla mutta myös sillä, että selviytymiskielitaidon tasolla kielenoppijat tarvitsevat ensi sijassa suullisen viestinnän taitoja.

Kielitutkintotyöryhmän jäsenet katsoivat, että 13 vuotta aiemmin asetetut tavoitteet opetuksen sisällön ja opetusmenetelmien uudistamisesta ovat toteutuneet. Kielitutkinnolla on ollut siinä oma, velvoittava rooli, mutta tätä tavoitteiden mukaista muutosta on tukenut opettajien täydennyskoulutus. Niin Wall ja Alderson (1993) kuin myös Cheng (2014, s. 2483) ovat todenneet, että mitä arvioidaan, sitä pidetään arvokkaana ja opetettavana. Tämä kuului myös paluumuuttovalmennuksen opettajien puheessa. Kielitutkinto räätälöitiin Suomeen muuttavien selviytymiskielitaidon arvioimiseen, ja aiheet olivat monipuolisempia kuin esimerkiksi matkailuun suuntautuvalla kielikurssilla. Opettajat pitivät laajaa aihevalikoimaa ja puhumisen tärkeää asemaa perusteltuna juuri Suomeen muuton kannalta.
Aiheuttiko tutkinto sitten ei-toivottuja tai muita odottamattomia vaikutuksia? Stressivaikutus sekä opiskelijoiden että myös opettajien kohdalla oli varmasti odotuksenmukainen. Tässä aineistossa stressi tai jännitys ei korostunut, vaikka kyseessä ollut tutkinto oli sen suorittajien kannalta erittäin merkittävä, niin sanottu high-stakes -tutkinto. Siitä riippui osaltaan oleskeluluvan saaminen inkeriläisstatuksella. Tutkinto oli osa paluumuuttoa, ja sillä oli prosessissa oma vakiintunut asemansa. Ehkä hiukan yllättävää oli opettajien varsin myönteinen suhtautuminen kielitaidon testaamiseen virallisen tutkinnon keinoin. Yhtenä selittävänä tekijänä tälle myönteisyydelle saattaa olla se, että niin kielitutkintoa kuin myös paluumuuttovalmennusta rahoittivat Suomen viranomaiset. Tutkinto oli valmennuskurssin päätös, ja niin kurssi kuin myös tutkinto olivat osallistujille ilmaisia. Tässä suhteessa Dipaki erosi useimmista muista kielitutkinnoista.

Dipaki-kielitutkinnolle muodostui vankka asema osana paluumuuttoprosessia. Kielitaito, jota yleensä pidetään pehmeänä arvona (soft skill), sai merkittävän painoarvon maahanmuuton hallinnollisessa prosessissa. Kielitutkinnon ansiosta kielenopettajien merkitys kasvoi, samoin kielitutkintosuorituksia arvioineiden, Suomessa toimivien suomen kielen opettajien, kun kielitaidon osoittaminen oli yksi vaadittu edellytys oleskeluluvan saamiselle. Tutkinto pyrittiin kielitutkintotyöryhmän asiantuntijajäsenen mukaan toteuttamaan kansainvälisiä ALTEn kielitutkinnon laatukriteereitä noudattaen (esimerkiksi ALTE 2008; 2016). Tutkinnon asiantunteva ja huolellinen suunnittelu oli mahdollisesti yhtenä syynä siihen, että opettajat pitivät tutkintoa omaa opetustyötään tukevana. Tutkintotyöryhmän jäsenten ja valmennuskurssien opettajien mielestä oli onnistuttu tutkinnon tavoitteiden asettamisessa, kontekstiin soveltuvan tutkinnon sisällön ja toteutusta- 
van luomisessa sekä tuessa opettajille ja sitä kautta oikeanlaisessa valmentautumisessa tutkintoon. Kielitutkinnon päättyminen oli osa yhteiskunnallista prosessia, kun paluumuutto inkeriläisstatuksen perusteella päättyi vuonna 2016. Vaikka tutkinnon vaikutukset olivat myönteisiä, ei tutkinnon järjestämiselle ole enää sitä tarkoitusta, joka sillä aikaan oli.

Henrichsenin malli innovaation käyttöönotosta opetuksessa (Henrichsen 1989) oli tarkasteltavaan ilmiöön sopiva, mutta tämä tutkimus onnistui kattamaan vain pienen osan mallin kuvaamista toiminnoista. Kuvaus menneisyydestä perustui tässä kahteen asiakirjaan ja asiantuntijoiden yksittäisiin repliikkeihin siitä, mihin tutkinnolla haluttiin muutosta. Systemaattiseen tiedonkeruuseen menneisyydestä laajemmin ei tutkimuksen toteutusajankohdan vuoksi (tutkinnon käyttöönoton jälkeen) ollut mahdollisuutta. Sisällönanalyysi oli sopiva työtapa, ja tutkimuksen keskiössä olleista opettajien näkemyksistä opettajien asettuminen (Henrichsenin, 1989 mallin mukaan) innovaation vastaanottajiksi kuvastaa hyvin sitä asemaa, johon he asettuivat valmentaessaan opiskelijoita kielitutkintoon. Tutkimuksellani onnistuin osoittamaan joitakin tutkinnon aiheuttamia, varsinkin suoria ja silminnähtäviä vaikutuksia. Vaikutukset olivat myös jatkuvia, sillä tutkinto oli käytössä 13 vuotta ja toivotut vaikutukset näkyivät vielä viimeisenä vuonna. Tutkinnolla ja siihen liittyvällä koulutuksella lienee ollut vaikutusta myös opetuskäytäntöihin tutkintoon valmentautumiskursseja laajemminkin: eräs opettaja (O4) totesi, että hän käyttäisi samantyyppisiä tehtäviä myös muilla kursseilla, koska hän oli huomannut ne toimiviksi.

Tutkintoon valmistautuneita ja tutkinnon suorittaneita ei tässä tutkimuksessa ole kuultu lainkaan. Koska asiantuntijatahojen käsitykset tutkinnosta ovat näin kovin myönteiset, jatkossa selvitetään, ovatko myös kielenoppijat kokeneet tutkinnon yhtä motivoivana, aiheet ja opetusmenetelmät yhtä hyödyllisinä ja testitaitojen kehittymisen yhtä tärkeänä elinikäisen oppimisen taitona.

\section{AINEISTOLÄHTEET}

Työministeriö (2003a). Inkerinsuomalaisten paluumuuttajien kielitestin perusteet. Helsinki: Työministeriö.

Työministeriö (2003b). Ulkomaalaislain 18 a §:n toimeenpanoa koordinoivan työryhmän asettaminen. Asiakirja 1.4.2003.635/021/2003TM. Helsinki: Työministeriö.

\section{LÄHTEET}

ALTE $2008=$ Language tests for social cohesion and citizenship - an outline for policymakers. Strasbourg: Language Policy Division. Council of Europe. Haettu 17.6.2016 osoitteesta https:// rm.coe.int/CoERMPublicCommonSearch Services/DisplayDCTMContent?documentId $=09000016802 \mathrm{fc} 1 \mathrm{~b} 9$.

ALTE 2016 = Kielitestin avulla osalliseksi, integroituneeksi ja kansalaiseksi. Opas päätöksenteon tueksi. Cambridge: Association of Language Testers in Europe.

Cheng, L. (2004). The washback effect of a public examination change on teachers' perceptions toward their classroom teaching. Teoksessa L. Cheng, Y. Watanabe \& A. Curtis (toim.), Washback in language testing. Research contexts and methods, (s. 147-170). Mahwah, New Jersey: Lawrence Erlbaum.

Cheng, L. (2008). Washback, impact and consequences. Teoksessa E. Shohamy \& N. H. Hornberger (toim.), Encyclopedia of language and education, Vol 7, (s. 2479-2494). New York: Springer Science + Business Media LLC.

Cheng, L. (2014). Consequences, impact and washback. Teoksessa A. J. Kunnan (toim.), The Companion to Language Assessment, (s. 24792494). New York: John Wiley \& Sons, Inc.

Cheng, L. \& Curtis A. (2004). Washback or backwash: A review of the impact of testing on teaching and learning. Teoksessa L. Cheng, Y. Watanabe \& A. Curtis (toim.), Washback in language testing. Research contexts and method, (s. 3-18). Mahwah, New Jersey: Lawrence Erlbaum. 
Davydova, O. (2002). Interaktiivista identiteettipeliä - havaintoja paluumuutosta Suomeen. Teoksessa S. Laihiala-Kankainen, S. Pietikäinen \& H. Dufva (toim.), Moniääninen suomi. Kieli, kulttuurija identiteetti,(s. 154-168). Jyväskylän yliopisto. Soveltavan kielentutkimuksen keskus.

Henrichsen, L.E. (1989). Diffusion of innovations in English language teaching: The ELEC Effort in Japan, 1956-1968. New York: Greenwood Press.

Kärkkäinen, K. \& Lankinen, J. (2008). Computerdelivered test of Finnish for Ingerian returnees. The 5th Annual EALTA Conference 8th - 11th May 2008. Hellenic American Union, Athens, Greece. Haettu 17.6.2016 osoitteesta http:// www.ealta.eu.org/conference/2008/docs/ posters/Dipaki_handout.pdf.

Loumbourdi, L. (2014). The Power and impact of standardized tests: Investigating washback on language exams in Greece. Frankfurt/Main: Peter Lang.

Maahanmuuttovirasto (2015). Kielitutkinto paluumuuttajille. Maahanmuuttovirasto. Haettu 17.6.2016 osoitteesta http://www.migri.fi/ paluumuutto/paluumuuttaja_entisen_ neuvostoliiton_alueelta/hakemuksen_ jattamisen_edellytykset/kansallisuudeltaan_ suomalainen/kielitutkinto.

Martikainen, M. (2016). Inkeriläisten paluumuuttajien kielitutkinnon synty keskustelussa. Teoksessa A. Huhta \& R. Hildén (toim.), AFinLAe: Kielitaidon arviointitutkimus 2000-luvun Suomessa, (s. 44-67). AFinLA-e. Soveltavan kielitieteen tutkimuksia 2016 / n:o 9.

Menken, K. (2007). High-stakes tests as de facto language education policies. Teoksessa E. Shohamy \& N. Hornberger (toim.), The encyclopedia of language and education, $\mathrm{Vol} 7$, (s. 401-414). Kluwer: Springer.

Messick, S. (1996). Validity and washback in language testing. Language Testing, 13, 241-256.

Mielonen, R. (2014). Inkerinsuomalaisten paluumuuttovalmennuskoulutus. Lukuvuosi 20132014 Pietarissa, Hatsinassa ja Petroskoissa. Loppuraportti. Etelä-Kymenlaakson ammattiopisto. Julkaisematon raportti.

Mielonen, R. (2016). Inkerinsuomalaisten paluumuuttovalmennuskoulutuksen viimeinen loppuraportti lukuvuodelta 2015-16 Pietarissa ja Petroskoissa. Etelä-Kymenlaakson ammattiopisto. Julkaisematon raportti.
Moore, S., Stroupe R. \& Mahony P. (2009). Perceptions of IELTS in Cambodia: A case study of test impact in a small developing country. Teoksessa J. Osbourne (toim.), IELTS report 6, Vol 13, (s. 293-401). Melbourne/Manchester: IELTS Australia and British Council.

Pietikäinen, S. (2012). Kieli-ideologiat arjessa. Neksusanalyysi monikielisen inarinsaamenpuhujan kielielämäkerrassa. Virittäjä, 3, 410-442.

Pietikäinen, S. \& Mäntynen A. (2009). Kurssi kohti diskurssia. Tampere: Vastapaino.

Pöyhönen, S. (2003). Uraopettajia, juurilleen palaajia ja kielenharrastajia. Suomen kielen opettajien ammatti-identiteetti Venäjän koulutuksen ja opetuksen murroksessa. Väitöskirja. Jyväskylän yliopisto. Soveltavan kielentutkimuksen keskus.

Rantala, T. (2006). Etnografisen tutkimuksen perusteet. Teoksessa J. Metsämuuronen (toim.), Laadullisen tutkimuksen käsikirja, (s. 216280). Helsinki: International Methelp.

Saville, N. (2013). Language testing and immigration. Teoksessa C. A. Chapelle (toim.), The encyclopedia of applied linguistics. Hoboken, New Jersey: Blackwell Publishing Ltd.

Tuomi J. \& Sarajärvi A. (2002). Laadullinen tutkimus ja sisällönanalyysi. Helsinki: Tammi.

Van Avermaet, P. \& Pulinx, R. (2014). Language testing for immigration to Europe. Teoksessa A. J. Kunnan (toim.), The Companion to Language Assessment, (s. 376-389). John Wiley \& Sons, Inc. I: 3: 22.

Vehkalahti, K. (2014). Kyselytutkimuksen mittarit ja menetelmät. Helsinki: Finn Lectura.

Wall, D. (1997). Impact and washback in language testing. Teoksessa C. Clapham \& D. Corson (toim.), Encyclopedia of language and education, (s. 291-302). Dordrecht: Kluwer Academic.

Wall, D. \& Alderson J. C. (1993). Examining washback: The Sri Lankan impact study. Language Testing, 10, 41-69.

Wall, D. \& Horák T. (2006). The impact of changes in the TOEFL examination on teaching and learning in Central and Eastern Europe. Phase 1, the baseline study. ETS Research Report Series 1, i-199. Haettu 22.8.2016 osoitteesta http://onlinelibrary.wiley.com/ doi/10.1002/j.2333-8504.2006.tb02024.x/ epdf. 
Wall, D. \& Horák T. (2008). The impact of changes in the TOEFL examination on teaching and learning in Central and Eastern Europe. Phase 2, coping with change. TOEFL iBT Research Report No. iBT-05. Haettu 22.8.2016 osoitteesta http://onlinelibrary.wiley.com/ doi/10.1002/j.2333-8504.2008.tb02123.x/ epdf.
Watanabe, Y. (2004). Teacher factors mediating washback. Teoksessa C. Liying, Y. Watanabe. \& A. Curtis (toim.), Washback in language testing. Research contexts and methods, (s. 129-146). Mahwah, New Jersey: Lawrence Erlbaum.

\section{LANGUAGE EXAM SETS GUIDELINES FOR TEACHING AND MOTIVATES SPEAKING}

Minna Martikainen, University of Jyväskylä

This is a study on washback of a language exam in Ingrians' language course in 2003-2016. Ingrians are ethnic Finns who have been living in Russia for many generations. In order to immigrate to Finland on the basis of Finnish origin they had to prove Finnish language skills in A2 level. In this research I analyze how the teachers describe the washback of the exam on their teaching. The teachers were working in Russia, teaching Finnish to Ingrians who intended to move to Finland. The data consists mainly of interviews with the teachers and with the specialists of the language exam committee. In the interviews I asked the teachers to describe how the exam has influenced teaching content and methods and the atmosphere in the classroom. The strongest washback was on teaching content and methods, especially oral exercises, students' good motivation and transparent objectives for the language course.

Keywords: Finnish language, impact, Ingrians, language exams, washback 
